THE INTERNATIONAL

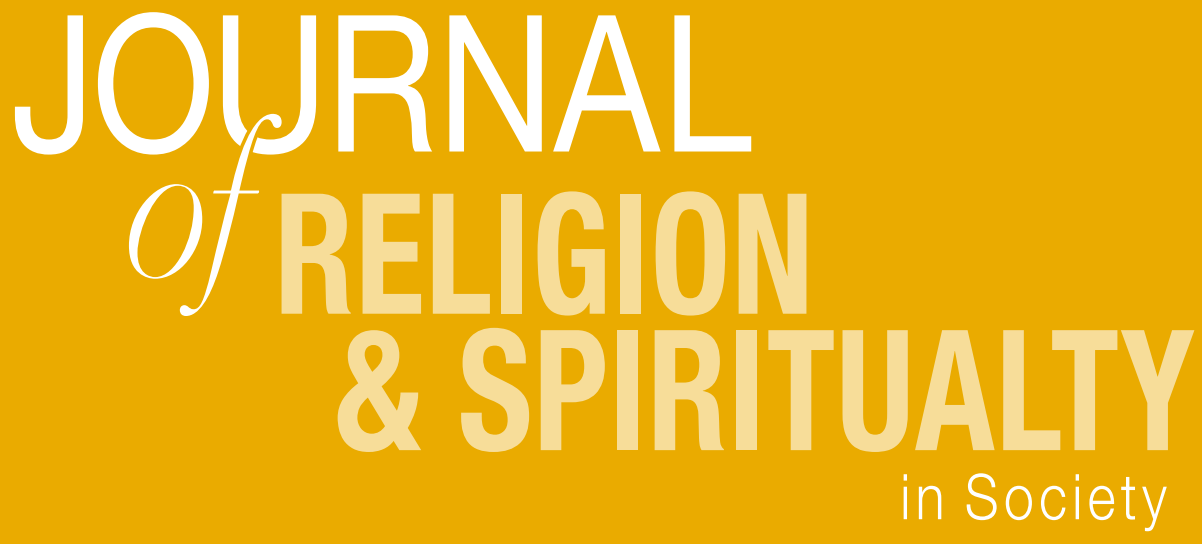

Volume 1, Number 2

From Abstraction to Action: Safeguarding Oral Traditions Using Digital Libraries

Karim Tharani 
THE INTERNATIONAL JOURNAL OF RELIGION AND SPIRITUALITY IN SOCIETY http://religioninsociety.com/journal/

First published in 2011 in Champaign, Illinois, USA

by Common Ground Publishing LLC

www.CommonGroundPublishing.com

ISSN: 2152-7857

(C) 2011 (individual papers), the author(s)

(c) 2011 (selection and editorial matter) Common Ground

All rights reserved. Apart from fair dealing for the purposes of study, research, criticism or review as permitted under the applicable copyright legislation, no part of this work may be reproduced by any process without written permission from the publisher. For permissions and other inquiries, please contact

<cg-support@commongroundpublishing.com>.

THE INTERNATIONAL JOURNAL OF RELIGION AND SPIRITUALITY IN SOCIETY is peer-reviewed, supported by rigorous processes of criterion-referenced article ranking and qualitative commentary, ensuring that only intellectual work of the greatest substance and highest significance is published.

Typeset in Common Ground Markup Language using CGPublisher multichannel typesetting system

http://www.commongroundpublishing.com/software/ 


\title{
From Abstraction to Action: Safeguarding Oral Traditions Using Digital Libraries
}

\author{
Karim Tharani, University of Saskatchewan, Saskatchewan, Canada
}

\begin{abstract}
Digital technologies are evolving and new ways of managing, accessing and disseminating information are continuously emerging. Ethnocultural communities with rich intangible cultural heritage need not be threatened by these developments. Although the rules governing the access of sacred traditions and knowledge in many ethnocultural communities are intricate, digital technologies can be adapted and leveraged to address local needs and constraints. Digital libraries, for example, have the potential to enhance the existing processes of safeguarding oral traditions within non-Western communities in ways that may not have been possible in the past. Unfortunately digital libraries, particularly in the West, have been stigmatized as tools for unrestricted access transcending space and time. This is a fundamental barrier for leaders of non-Western communities wishing to digitally safeguard their heritage. On one hand there may be desire in these communities to build digital libraries to manage and preserve culturally sensitive materials, but on the other hand, due to the very nature of some of these materials, the access to these digital collections cannot be left unrestricted. Drawing from the implementation of a digital library of gināns, a sacred oral tradition of the Ismaili Muslims of South Asia, this paper showcases how ethnocultural and religious communities can utilize digital library technology to safeguard sacred oral traditions based on their local contexts. The initial part of the paper proposes a conceptual design for a digital library of gināns using the Functional Requirements for Bibliographic Records (FRBR) model and the Dublin Core (DC) metadata standard. Using this conceptual model as the basis, the latter part of the article demonstrates the process of building a digital library using the Greenstone digital library software.
\end{abstract}

Keywords: Gināns, Digital Library, Sacred Oral Traditions, Intangible Cultural Heritage (ICH), Digital Technologies, Ethnocultural Communities, Ismaili Muslims, FRBR, Greenstone Digital Library Software, The Institute of Ismaili Studies (IIS)

A

N IMPORTANT PREREQUISITE for a community to safeguard its oral traditions is the willful acceptance of these traditions by successive generations. This acceptance, as Kurin points out, must be genuine and cannot be derived "through such coercive forms as legally requiring the sons and daughters who practise a tradition to continue in their parents' footsteps" (Kurin, 2004). In addition, community members must be willing to memorize and pass on the work to their successors. Since memorization of oral traditions is vulnerable to human errors and improvisations (Chadwick and Chadwick, 1986), many communities adopt a fixed form method for transmitting oral traditions to minimize loss of originality. With this method, oral traditions are rendered to written texts, often referred to as the transitional texts (Culley, 1963).

The current pervasiveness of digital technologies can help enhance the existing processes of transmitting oral traditions in ways that may not have been possible in the past. For example, using digital sound to capture oral traditions affords the flexibility of facilitating learning and transmission of these traditions in an asynchronous or on-demand mode. In

The International Journal of Religion and Spirituality in Society Volume 1, Number 2, 2011, http://religioninsociety.com/journal/, ISSN 2152-7857 
other words, use of digital media allows oral traditions to be extracted from knowledge bearers and held for transmission to receivers as and when needed. Another "potential benefit to making traditional knowledge accessible in a digital format is that this may make it more appealing to youth or others who may see traditional knowledge as old-fashioned" (Stevens, 2008). Thus leaders of ethnocultural communities with rich cultural heritage have a unique opportunity to capitalize on the conveniences of digital technologies to provide new ways for younger generations to learn and benefit from their cultural heritage.

Another digital technology that also holds great potential to enhance existing processes of safeguarding oral traditions within non-Western communities is digital libraries. Unfortunately digital libraries in the West have been stigmatized as tools for unrestricted access transcending space and time. For example, the President's Information Technology Advisory Committee (PITAC) in the United States defined digital libraries as "the networked collections of digital text, documents, images, sounds, scientific data, and software that are the core of today's Internet and tomorrow's universally accessible digital repositories of all human knowledge" (Chen, et. al., 2005). Such a narrow view of digital libraries as access tools not only undermines the true capabilities of digital libraries in general, but also discourages their use in non-Western communities in particular. As Derlon and Mauze suggest this "ideology of democratic and free access ... runs up against the issue of 'sacred' or 'culturally sensitive' objects insofar as many of these are subject to restrictions on access" (Derlon, and Mauze, n.d).

The rules governing the access of sacred traditions and knowledge are typically intricate and context-driven in many ethnocultural communities (Hunter, 2005). According to Hunter, this is a crucial consideration for community stewards and leaders wishing to digitally safeguard culturally sensitive materials. On one hand there may be desire in these communities to build digital libraries to preserve, share, and transmit traditional knowledge, but on the other hand, due to the very nature of some of these materials, the access to these digital collections need to be strictly controlled.

The ability to provide access to distributed collections transcending time and space is, no doubt, one of the cherished benefits of the digital libraries, but digital libraries are more than mere access tools. The Digital Library Federation, quite appropriately, defines digital libraries as "organizations that provide the resources, including the specialized staff, to select, structure, offer intellectual access to, interpret, distribute, preserve the integrity of, and ensure the persistence over time of collections of digital works so that they are readily and economically available for use by a defined community or set of communities" (DLF, 1998).

Thus, contrary to the popular perception of digital libraries as universal access tools, a proper digital library is designed, implemented and adapted based on well-defined needs of its potential user community. Maurita Holland, co-founder of the Cultural Heritage Preservation Institute, points out that the onus ought to be on community leaders to overcome their dogmatic lack of trust for the Western technologies and make their needs known to technologists (Holland, 2002):

Inevitably, technology will have an impact ... This impact needs to be anticipated and carefully considered. On one point, digital library technologists and cultural leaders very much agree: when developing digital libraries ... it is critically important to begin with an understanding of what the goals of such development are and with agreement about what the responsibilities of the stakeholders will be. Technologists can suggest 
what's technically possible, but they need to be sensitive to the culture and needs ... Cultural leaders need to make their needs and aspirations known to the technologists. The resulting digital library should be reflective of this mutual understanding and agreement.

\section{Gināns - A Sacred Oral Tradition of the Ismailis}

The oral tradition of gināns, a collection of sacred religious hymns of the Ismailis ${ }^{1}$, serves as a good case in point. The gināns were initially passed on orally but the Ismaili community members started rendering them to text starting in the eighteenth century. There is evidence that the gināns were written down using a special script called Khojki, developed and used almost exclusively by the Ismaili community to preserve the sanctity of its religious literature (Esmail, 2002). The Institute of Ismaili Studies (IIS) in England, established for promoting scholarship in Ismaili and other Shia sects of Islam, has a distinctive collection of such Khojki manuscripts in its Library (IIS, 2010). The community has successfully preserved this knowledge by transcribing and translating gināns in various languages to ensure its transmission from one generation to the next.

Today, the Ismaili community lives in more than twenty-five countries around the world including the United States, Canada and the United Kingdom (IPL, 2009). Despite this geographical diversity, the oral tradition of gināns remains alive and continues to play a vital role in the religious life of the community. The Ismaili community continues to draw from the knowledge embedded in this melodic oral tradition, which encompasses "the meaning of life; the values by which it ought to be guided; the pathos of death; and the hope, beyond death, of salvation and fulfillment" (Esmail, 2002). The recitation of gināns is part of religious rituals in jamatkhanas where the members of the Ismaili community congregate daily for morning and evening prayers (Asani, 2002). Since gināns have assigned ragas (melodies) that must also be mastered together with the lyrics for recitation during congregations (Esmail, 2002), the young in the community continue to learn gināns from their elders in both formal and informal settings. It is also not uncommon to find audiocassettes, CDs and digital audio files of the gināns among the community members (Asani, 2002).

Given the success of the Ismaili community in safeguarding gināns, the use of digital library technology for gināns must be seen as means of enhancement, and not replacement of the transmission process already in place within the Ismaili community. Implementing a digital library of gināns can make gināns more accessible for learning and research. In addition, having an organized and accessible digital library of gināns may also stimulate a deeper, and much needed, engagement of community scholars with this sacred corpus of knowledge. As Kassam points out in her book Songs of Wisdom and Circles of Dance (Kassam, 1995):

Ginānic vocabulary is also peppered with loan words from Persian, Arabic, and Sanskrit. The songs are rich in imagery and symbolism drawn from the spiritual and cultural milieu of the Indian subcontinent. ... The entire ginān corpus consists of about one thousand works whose lengths vary from five to four hundred verses. Less than a tenth

\footnotetext{
${ }^{1}$ The Ismailis are ethnically diverse community of Shia Muslims with rich cultural and intellectual heritage. More information on the community can be found at http://www.theismaili.org
} 
of this sizable vernacular South Asian Muslim literature has been edited and translated, much less analyzed.

Using gināns as an example, the following sections will illustrate the process of designing, implementing and using digital libraries to safeguard and share sacred oral traditions in a community setting.

\section{Designing a Digital Library of Gināns}

Unlike physical libraries where the availability and well being of information carriers (like books, CDs, DVDs, etc.) is an important consideration, digital libraries are not constrained by artifacts and tend to focus on the integration of resources of the collection. This is a very beneficial feature of digital libraries for digitally safeguarding cultural works like gināns. Although the core body of the ginānic works has been static since the early twentieth century, today a single ginānic work may have several resources associated with it (see Figure 1). For example, a ginān may have been rendered to text in various languages and may also have accumulated several transcriptions, translations as well as oral renditions over time to facilitate transmission and learning.

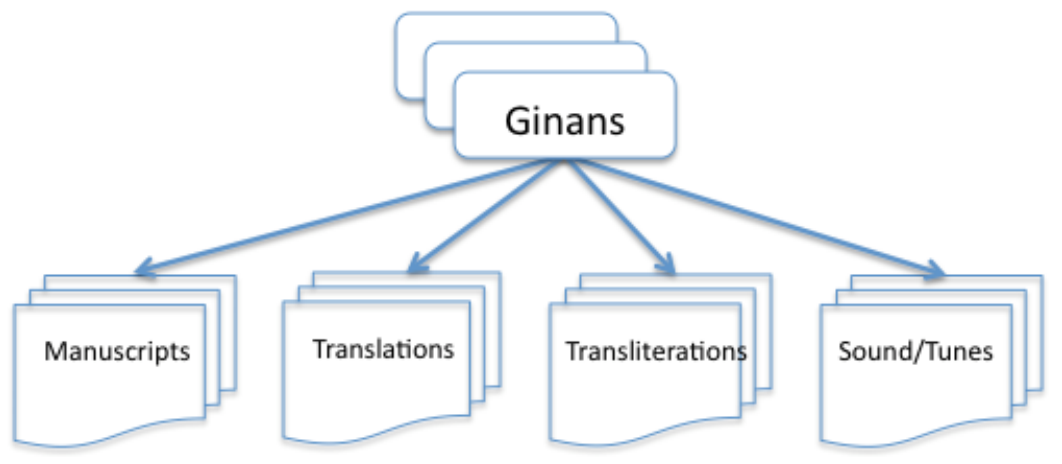

Figure 1: Forms of Transmission of the Ginānic Collection

Thus a well-designed digital library of gināns must be able to accept the plurality of ginānic works and must also seamlessly manage the multiplicity of associated resources, in form and content. The table below is a summary of the ginānic collection as it exists today. 
Table 1: Forms and Contents of the Ginānic Collection

\begin{tabular}{|l|l|l|}
\hline Form & Content & Purpose \\
\hline Manuscripts & $\begin{array}{l}\text { Scanned images of gināns in } \\
\text { Khojki script. }\end{array}$ & $\begin{array}{l}\text { Preserve and provide access to the } \\
\text { primary ginānic scriptures. }\end{array}$ \\
\hline Sound/Tunes & $\begin{array}{l}\text { Audio files with melody as- } \\
\text { signed to the gināns. }\end{array}$ & $\begin{array}{l}\text { Preserve and provide access to the tradi- } \\
\text { tional melodies of the gināns. }\end{array}$ \\
\hline Transliterations & $\begin{array}{l}\text { Text in Roman script and other } \\
\text { languages. }\end{array}$ & $\begin{array}{l}\text { Make it easier to follow and recite the } \\
\text { gināns. }\end{array}$ \\
\hline Translations & $\begin{array}{l}\text { Translation of gināns in Eng- } \\
\text { lish, Gujarati, etc. }\end{array}$ & $\begin{array}{l}\text { Promote understanding and learning of } \\
\text { the gināns. }\end{array}$ \\
\hline
\end{tabular}

The Functional Requirements for Bibliographic Records (FRBR) model for Products of Intellectual and Artistic Endeavor (FRBR Group 1 Entities) developed by the International Federation of Library Associations and Institutions (IFLA) was leveraged for designing the digital library of gināns. This model affords better handling of oral tradition works, especially when other auxiliary resources are also attached to the core work (Nicolas, 2005) as in the case of the gināns. An additional feature of adopting the IFLA model is that it rightly situates the works (gināns) at the center of the collection as opposed to manuscripts, books, audiocassettes, etc.

According to the FRBR model a work is a distinct intellectual or artistic creation, which is realized through expression. An expression, therefore, is the specific form that a work takes each time it is realized. The physical embodiment of an expression is referred to as a manifestation and a single exemplar of a manifestation is called an item in the IFLA model (IFLA, 1998). The application of the IFLA model to the oral tradition of gināns is better understood with an example. The ginān titled Eka Shabada Suno Mere Bhai (Hearken to this word of mine) is attributed to Pir Shams ${ }^{2}$. According to the IFLA model, this ginān is a work by Pir Shams that has an expression by virtue of its English translation by Aziz Esmail that finds its manifestation in a book titled 'A Scent of Sandalwood - Indo-Ismaili Religious Lyrics' available as an item through the website of The Institute of Ismaili Studies. ${ }^{3}$ The table below provides a summary of how the IFLA model has been applied to the ginānic collection for designing the proposed digital library of gināns.

\footnotetext{
${ }^{2}$ A ginān by Pir Shams: Eka shabada suno mere bhai. Available at The Institute of Ismaili Studies website: http://www.iis.ac.uk/view_article.asp?ContentID=105373 (Retrieved February 21, 2011).

${ }^{3}$ An English translation of the gināns is available at The Institute of Ismaili Studies website: http://www.iis.ac.uk/view_article.asp?ContentID=105328 (Retrieved February 21, 2011).
} 
Table 2: Leveraging IFLA Model for the Digital Library of Gināns

\begin{tabular}{|l|l|l|}
\hline FRBR Entity & Description & Example \\
\hline Work & $\begin{array}{l}\text { A work is a distinct intellectual or } \\
\text { artistic creation. }\end{array}$ & $\begin{array}{l}\text { The ginān titled Eka Shabada Suno } \\
\text { Mere Bhai attributed to Pir Shams }\end{array}$ \\
\hline Expression & $\begin{array}{l}\text { An expression is the intellectual } \\
\text { or artistic realization of a work. }\end{array}$ & $\begin{array}{l}\text { The English translation of the ginān } \\
\text { Eka Shabada Suno Mere Bhai by } \\
\text { Aziz Esmail. }\end{array}$ \\
\hline Manifestation & $\begin{array}{l}\text { A manifestation is the physical } \\
\text { embodiment of an expression of } \\
\text { a work. }\end{array}$ & $\begin{array}{l}\text { The English translation of the ginān } \\
\text { Eka Shabada Suno Mere Bhai by } \\
\text { Aziz Esmail published in the book A } \\
\text { Scent of Sandalwood - Indo-Ismaili } \\
\text { Religious Lyrics. }\end{array}$ \\
\hline Item & $\begin{array}{l}\text { An item is a single exemplar of a a copy of the English translation of } \\
\text { manifestation. }\end{array}$ & $\begin{array}{l}\text { A con ginān Eka Shabada Suno Mere } \\
\text { the } \\
\text { Bhai by Aziz Esmail accessible on the } \\
\text { website of The Institute of Ismaili } \\
\text { Studies. }\end{array}$ \\
\hline
\end{tabular}

\section{Content Forms and Formats}

Digital libraries are capable of working with multimedia resources of various formats. The ginānic collection consists of digitized images, texts as well as digital sound files in various formats as summarized in the table below.

Table 3: Content Forms and Formats of Digital Resources in the Digital Library of Gināns

\begin{tabular}{|l|l|l|}
\hline Content & Form & Format \\
\hline Scanned images of Khojki manuscripts & Image & TIFF, JPEG or PDF \\
\hline English transliterations and translations & Document & Word, Text, HTML, etc. \\
\hline $\begin{array}{l}\text { Non-English (Urdu, Gujarati, etc.) transcrip- } \\
\text { tion or translation of gināns }\end{array}$ & Image & TIFF, JPEG or PDF \\
\hline Audio files of gināns with melody & Audio & MP3 \\
\hline
\end{tabular}

\section{Metadata}

Metadata is usually defined as data about data. In the context of a digital library, metadata is the information that describes resources within the digital collection. The purpose of metadata is to make resources discoverable and accessible to the users during search and retrieval. Over the years several metadata standards have been defined and used to describe varying forms of information resources. The Dublin Core metadata standard, for example, was developed to describe and organize information resources in a digital environment. Given the diverse nature of the digital resources in the ginānic collection, the Dublin Core 
metadata standard was adopted for the proposed digital library of gināns. The table below illustrates how the elements of Dublin Core metadata standard are applied to describe ginānic resources.

Table 4: Use of Dublin Core Metadata Elements in the Digital Library of Gināns

\begin{tabular}{|l|l|}
\hline Dublin Core Element & Usage \\
\hline Title & Title of the ginān (work) \\
\hline Creator & Composer (or pir) to whom the ginān is attributed \\
\hline Subject & Key words to explain dominant themes in the ginān \\
\hline Description & Synopsis of the ginān where available \\
\hline Publisher & Publishing institute or organization \\
\hline Contributor & Name of translator, transcriber, etc. \\
\hline Date & Date associated with the resource, where available \\
\hline Type & Type of resource e.g. text, sound, image, etc. \\
\hline Format & Format of the resource e.g. audio/mpeg, text/html, etc. \\
\hline Identifier & Unique identifier for the resource \\
\hline Source & Name of the entity owning the resource \\
\hline Language & Language of the contents of the resource e.g. English \\
\hline Relation & Relationship to other gināns, if any \\
\hline Coverage & Time period and/or geographic location of the ginān \\
\hline Rights & Rights held in and over the ginānic resource \\
\hline
\end{tabular}

\section{Implementing the Digital Library of Gināns Using Greenstone}

The aforementioned conceptual design of the proposed digital library of gināns can be implemented using a variety of open-source digital library software available today. A strong candidate among the available software options is the Greenstone digital library software. Greenstone has "helped spread the practical impact of digital library technology throughout the world" and has also been used by various high-profile organizations such as UNESCO and BBC in support of their collections (Witten and Bainbridge, 2007). According to Witten and Bainbridge, Greenstone has been designed to empower community stewards and keepers of heritage materials to manage collections on their own. Greenstone was also recently recognized as the 'best performer overall' when compared to other digital library systems (Witten and Bainbridge, 2007).

Apart from being open source and easy to use with its browser-based interface, Greenstone has the ability to operate both in a networked (Internet) and non-networked (stand-alone) mode. This capability of Greenstone to work without the need to be connected to the Internet makes it an extremely good fit for managing sacred or sensitive digital resources that must have restricted access. Another feature that goes hand in hand with Greenstone's ability to work in a controlled environment is its ability to transfer entire digital collections (including 
software necessary to run the library system) on portable media like CD-ROMs. This feature is useful for creating backup archives and securely transferring sacred or sensitive collections from one place to another without requiring network connectivity. Furthermore, as Elaiess points out, "Greenstone software has a built-in access control mechanism that allows collections and even individual documents to be restricted to authorised users using a password protection scheme. This mechanism can be applied if the organisation prefers to apply restrictions on access to some specific content" (Elaiess, 2009). This flexibility also makes Greenstone a good candidate for implementing the digital libraries of sacred knowledge like gināns.

\section{Installing the Greenstone Digital Library Software}

Knowing that the "ease of acquiring and installing a software project has a direct impact on the users it attracts, and consequently - in the open source world — on the extent and nature of contributions that users make to the project", the Greenstone software has been specifically designed to make the installation process easier for end-users with limited technical skills (Witten and Bainbridge, 2007). The installation files for the Greenstone digital library software can be downloaded from their official website. ${ }^{4}$ Due to its large install-base, Greenstone enjoys a healthy support of development and user community, which translates into having access to good documentation and technical support. The digital library of gināns was developed using version 2.74 of Greenstone software. This version provides administrative screens under its Librarian Interface for keepers and administrators of the collection to manage and maintain the underlying digital resources.

\section{Building the Digital Library Using Greenstone's Librarian Interface}

With the Greenstone software installed, the process of creating a basic digital library is fairly structured and straightforward. The building of the digital library is facilitated by Greenstone's Librarian Interface, which breaks down the process into discrete steps (see Figure 2 below). The Greenstone user's guide also provides details on the more advanced features for the steps described below (NZDLP, 2007).

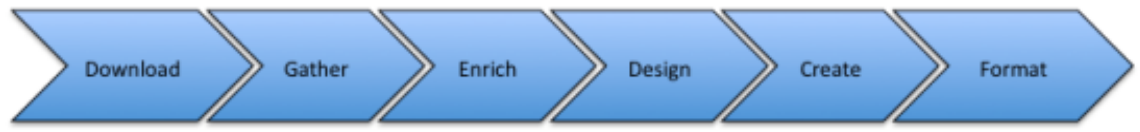

Figure 2: The Process of Building Digital Library with Greenstone Digital Library Software

\section{Download}

Greenstone provides an option for administrators to harvest resources from the Web through its Download screen. This is a process to accumulate web-based resources to be loaded to the digital library. This particular feature was not used in the implementation of the proposed digital library of gināns as the necessary resources were digitized and stored locally.

\footnotetext{
${ }^{4}$ The official website to download Greenstone Digital Library software is http://www.greenstone.org/download.
} 


\section{Gather}

This is the process of defining folder structures for the digital library. The Gather screen (see Figure 3 below) lets librarians and administrators define and load local files and resources to the digital library. Based on the proposed design of the digital library of ginanns, the ginānic digital resources were categorized into four folders - manuscripts, translations, transliterations, and tunes.

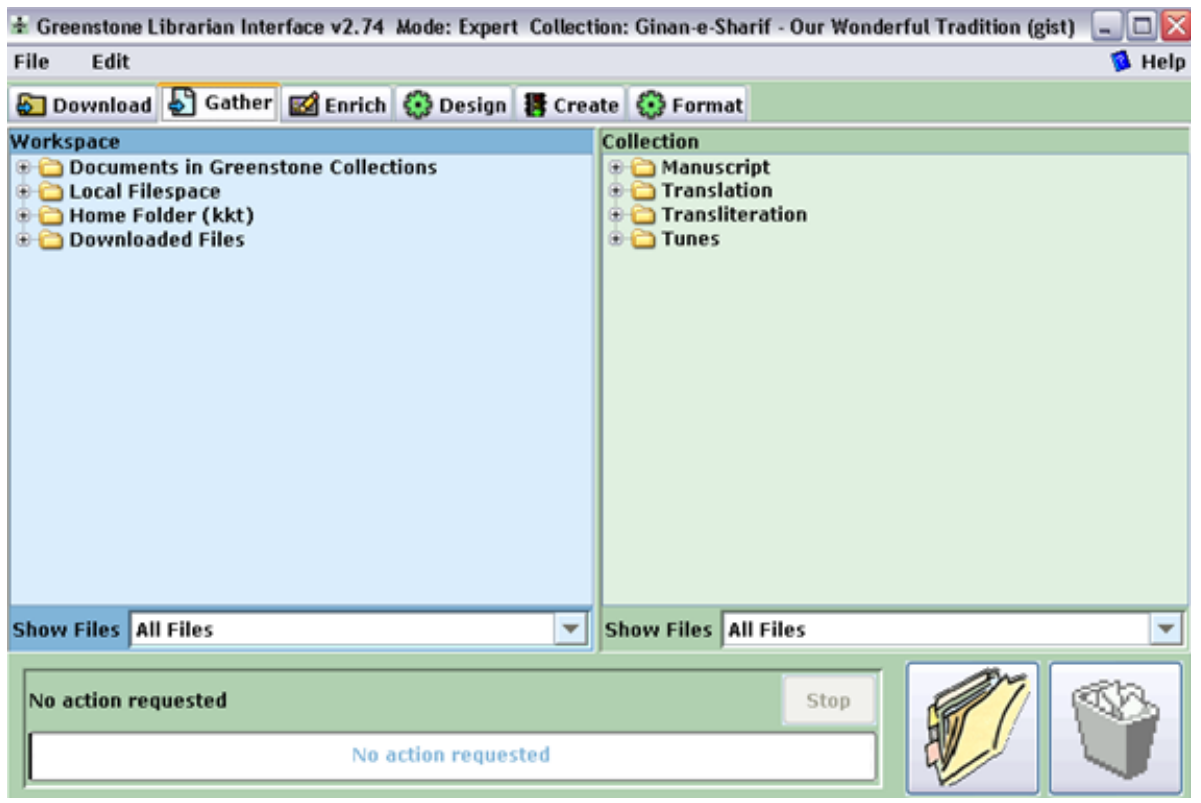

Figure 3: Greenstone’s Librarian Interface

\section{Enrich}

The Enrich screen enables administrators to describe digital resources by adding metadata to be loaded to the digital library. Administrators can choose from built-in metadata sets such as Dublin Core or design custom metadata set using the Metadata Manager functionality. Greenstone allows metadata to be added both at the folder and item level. The Librarian Interface within the Greenstone software supports the Dublin Core metadata standard and provides tools to manage the metadata information. As mentioned before, the built-in Dublin Core metadata set was used for the digital library of gināns.

\section{Design}

The design preferences for a digital library are defined using the parameters provided by the Design screen. In addition to setting collection name, description and contact information, administrators can select plug-ins (viewers) for their digital resources from a built-in library of available plug-ins within Greenstone. The search and classifier settings are also specified in this view. A classifier allows underlying resources to be presented and sorted using spe- 
cific attributes. In the case of gināns, the classifiers were defined using ginān titles, pirs (composers), institutes, category (e.g. manuscript, transcription, etc.) and contributors.

\section{Create}

In this step administrators can invoke Greenstone's collection-building scripts by click of a single button to create their digital library. At the end of this process, the digital library is ready for preview and use.

\section{Format}

The initial user interface generated by the Greenstone software is typically basic and visually unappealing. However, Greenstone allows its interface to be extended with its Format interface. The format strings can also be used to customize certain aspects of the user interface of their digital library. The customized user interface of the proposed digital library of gināns is shown below (see Figure 4).

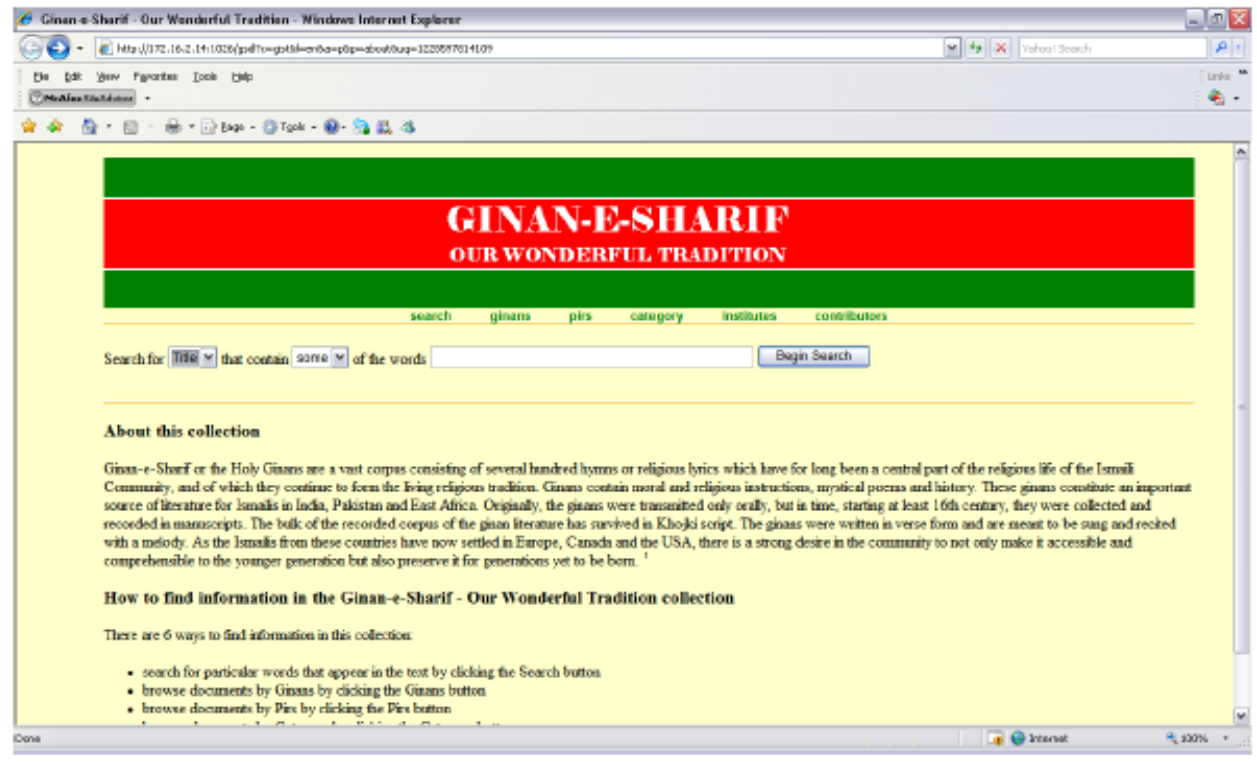

Figure 4: User Interface of the Digital Library of Gināns

\section{Using the Digital Library of Gināns}

As mentioned before, the Greenstone digital library provides a web-based interface for its users to search and access digital resources. For example, to view the collection by types of resources available (e.g. manuscripts, translations, transliterations, etc.) in this digital library of gināns, users can click on the category classifier, which appear as links just below the main header (see Figure 5). The number of underlying resources within each of these categories is also displayed. Based on the design of the digital library of gināns, the manuscripts have been organized as a collection of pages pertaining to a particular ginān. This approach 
saves users from having to browse through entire manuscripts to locate a particular ginān. The English translations and transcriptions within the digital library of gināns are also automatically indexed for full-text searching. Users can also choose to limit their search only to the titles of gināns or expand their search to include available English transliterations and translations. With the search interface, users can instruct the search engine to either look for all or some of the words provided by them in the search string. The returned resources in the search results are presented with relevant icon to indicate their type (e.g. sound, text, image, etc.) The tunes category can be used to browse through the available digital audios of the gināns available in the library.

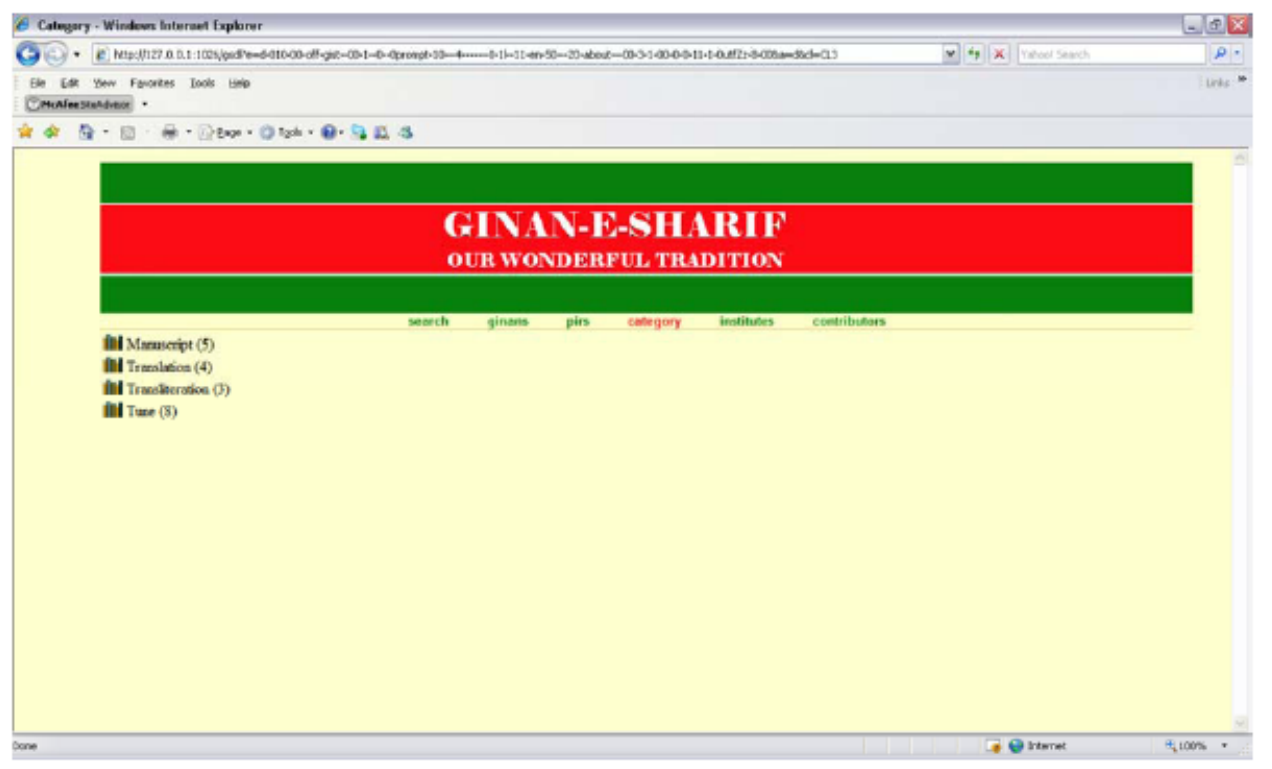

Figure 5: Browsing Resources by Category in the Digital Library of Gināns

\section{Conclusion}

The term intangible cultural heritage was formally defined in 2003 at the UNESCO Convention for the Safeguard of the Intangible Cultural Heritage as "the practices, representations, expressions, knowledge, skills that communities, groups and, in some cases, individuals recognize as part of their cultural heritage" (UNESCO, 2003). Oral traditions form a vital part of the intangible cultural heritage in many ethnocultural and religious communities as the knowledge is transmitted through "traditional songs, stories, legends, dreams, methods, and practices" (Fien, Heck, and Ferreira, 1999). In fact, the UNESCO Convention designated oral tradition as a "vehicle of the intangible cultural heritage." The UNESCO Convention, however, has been criticized for not specifying how communities can safeguard their intangible cultural heritage. As Kurin observes that "the Convention is clearly a work in progress wherein experts and community people, policy-makers and scholars will try to figure out how to safeguard cultures over the coming years" (Kurin, 2004). 
This paper is an attempt to put the UNESCO Convention's ideals into effect. In particular, it advocates utilizing digital library software like Greenstone to stimulate the existing practices of safeguarding sacred oral traditions within ethnocultural and religious communities. The use of digital library or other digital technologies, however, must be seen as means of enhancing, not replacing, the existing processes "which generations before us have ingeniously crafted and passed on to us in trust" (Smith, 1999).

Digital library technology presents a unique opportunity for communities with rich intangible cultural heritage to enhance their existing human-centric processes for safeguarding oral traditions. However, some community leaders may still be apprehensive about embracing digital technologies. In many indigenous communities, for example, digital technologies are still perceived as means of continuation of the historical process of colonization and appropriation by the West (Stevens, 2008). Another reason that may also be holding communities back, according to Steven, is the belief that digital surrogates reduce cultural knowledge to mere information that may be of little value outside the cultural context of a community. These are fair but stereotypical concerns that must addressed by community leaders and technologists together within well-defined local context and community requirements. Digital technologies are evolving and new ways of managing, accessing and disseminating information are continuously emerging. Ethnocultural and religious communities with rich intangible cultural heritage need not be threatened by these technologies, but must be courageous in evaluating, adapting, and leveraging them to address their local information needs.

\section{Acknowledgement}

The author is grateful to Professor Edie Rasmussen for her continuous guidance, encouragement and support throughout this project and beyond.

\section{References}

Asani, A. (2002). Ecstasy and enlightenment - The Ismaili devotional literature of South Asia. London: I. B. Tauris Publishers.

Chadwick, H. M., and Chadwick, N. K. (1986). The growth of literature: Volume II. Cambridge: Cambridge University Press.

Chen, C., Wactlar, H., Wang, J. Z., and Kiernan, K. (2005). Digital imagery for significant cultural and historical materials - An emerging research field bridging people, culture, and technologies. International Journal on Digital Libraries. 5(4), 275-286.

Culley, R. C. (1963). An approach to the problem of oral tradition. Vetus Testamentum, 12(2), 113125.

Derlon, B. \& Mauze, M. (n.d). "Sacred" or "sensitive" objects. Retrieved April 30, 2010, from http://www.necep.net/papers/OS_Derlon-Mauze.pdf.

DLF. (1998). A working definition of digital library. Digital Library Federation. Retrieved April 30, 2010, from http://www.diglib.org/about/dldefinition.htm

Elaiess, R. (2009). General guidelines for designing bilingual low cost digital library services suitable for special library users in developing countries and the Arabic speaking world. In Proceedings of the World Library and Information Congress: 75TH IFLA General Conference and Council (Milan, Italy, August 23 - 27, 2009). http://www.ifla.org/files/hq/papers/ifla75/175elaiess-en.pdf

Esmail, A. (2002). A scent of Sandalwood - Indo-Ismaili religious lyrics. Surrey: Curzon Press. 
Fien, J., Heck, D. and Ferreira J. (1999). Learning for sustainable environment: A professional development guide for teacher educator - Module 5: Indigenous knowledge. Retrieved April 30, 2010, from <http://www.ens.gu.edu.au/ciree/LSE/MOD5.HTM>.

Holland, M. P. (2002, March). We come from around the world and share similar visions. D-Lib Magazine, 8(3). Retrieved April 30, 2010, from http://www.dlib.org/dlib/march02/holland/03holland.html

Hunter, J. (2005). The role of information technologies in indigenous knowledge management. Australian Academic and Research Libraries, 36(2), 113-128.

IFLA. (1998). Functional requirements for bibliographic records : Final report. IFLA Study Group on the Functional Requirements for Bibliographic Records. International Federation of Library Associations and Institutions. München : K.G. Saur.

IIS. (2010). Manuscripts: Gujrati and the Khojki script. The Institute of Ismaili Studies. Retrieved April 30, 2010, from http://www.iis.ac.uk/view_article.asp?ContentID=104533

IPL. (2009). The Ismaili. Islamic Publications Limited. Retrieved April 30, 2010, from http://www.theismaili.org

Kassam, T. R. (1995). Songs of wisdom and circles of dance-Hymns of the Satpanth Ismaili Muslim saint, Pir Shams. Albany: State University of New York Press.

Kurin, R. (2004). Safeguarding intangible cultural heritage in the 2003 UNESCO convention: A critical appraisal. Museum International, 56(1-2). Retrieved April 30, 2010, from http://onlinelibrary.wiley.com/doi/10.1111/j.1350-0775.2004.00459.x/pdf

Nicolas, Y. (2005). Folklore requirements for bibliographic records: Oral traditions and FRBR. Cataloging \& Classification Quarterly, 39(3), 179-195. doi:10.1300/J104v39n03_11

NZDLP. (2007). Greenstone digital library - User's guide. New Zealand Digital Library Project Retrieved April 30, 2010, from http://www.greenstone.org/manuals/gsdl2/en/html/User_en_index.html

Smith, A. (1999). Why digitize? Council on Library and Information Resources. Retrieved April 30, 2010, from http://www.clir.org/pubs/reports/pub80-smith/pub80.html

Stevens, A. (2008). A different way of knowing: Tools and strategies for managing indigenous knowledge. Libri, 58, 24-33.

UNESCO. (2003). Convention for the safeguarding of intangible cultural heritage. Paris: UNESCO. Retrieved April 30, 2010, from http://unesdoc.unesco.org/images/0013/001325/132540e.pdf

Witten, I. H. and Bainbridge, D. (2007). A retrospective look at Greenstone: Lessons from the first decade. In Proceedings of the 7th ACM/IEEE-CS Joint Conference on Digital Libraries (Vancouver, BC, Canada, June 18 - 23, 2007).

\section{About the Author}

Karim Tharani

Karim Tharani is a Liaison Librarian for Religion and Culture as well as an Information Technology Librarian at the University of Saskatchewan in Saskatoon Canada. Tharani has a Bachelor of Science degree in Management and Systems Science from the Simon Fraser University in British Columbia, Canada. Tharani obtained his Master of Library and Information Studies (MLIS) degree from the University of British Columbia. Prior to joining the University Library, Tharani worked as an Information Technology Consultant at IBM Canada Ltd. 



\section{y.

\section{Editor}

Bill Cope, University of Illinois, Urbana-Champaign, USA.

\section{Editorial Advisory Board}

Desmond Cahill, Royal Melbourne Institute of Technology, Melbourne, Australia.

Bill Cope, University of Illinois, Urbana-Champaign, USA

Robert McKim, University of Illinois, Urbana-Champaign, USA

Please visit the Journal website at http://religioninsociety.com/journal// for further information about the Journal or to subscribe. 


\section{The Religion and Spirituality in Society Community}

This knowledge community is brought together by a common concern for religious study and an interest to explore the relationship between religion and spirituality in society. The community interacts through an innovative, annual face-to-face conference, as well as year-round virtual relationships in a web blog, peer reviewed journal and book series-exploring the affordances of the new digital media. Members of this knowledge community include philosophers, theologians, policymakers, and educators.

\section{Conference}

Members of the Religion and Spirituality in Society Community meet at the international conference, held annually in different locations around the world, each selected for the particular role education is playing in social, cultural and economic change. The Inaugural Conference was held at University Center, Chicago, USA in 2011 and in 2012 the Conference will be held at Robson Square, University of British Columbia, Vancouver, Canada.

Our community members and first time attendees come from all corners of the globe. The Conference is a site of critical reflection, both by leaders in the field and emerging artists and scholars. Those unable to attend the Conference may opt for virtual participation in which community members can submit a video and/or slide presentation with voice-over, or simply submit a paper for peer review and possible publication in the Journal.

Online presentations can be viewed on YouTube.

\section{Publishing}

The Religion and Spirituality in Society Community enables members to publish through three mediums.

First, by participating in the Religion Conference, community members can enter a world of journal publication unlike the traditional academic publishing forums - a result of the responsive, non-hierarchical and constructive nature of the peer review process. The International Journal of Religion and Spirituality in Society provides a framework for double-blind peer review, enabling authors to publish into an academic journal of the highest standard.

The second publication medium is through the book series Religion in Society, publishing cutting edge books on religion in print and electronic formats. Publication proposals and manuscript submissions are welcome.

The third major publishing medium is our news blog, constantly publishing short news updates from the Religion Community, as well as major developments in the fields of religion and spirituality. You can also join this conversation at Facebook and Twitter or subscribe to our email Newsletter. 


\section{Common Ground Publishing Journals}

\begin{tabular}{|c|c|}
\hline $\begin{array}{l}\text { AGING } \\
\text { Aging and Society: An Interdisciplinary Journal } \\
\text { Website: http://AgingAndSociety.com/journal/ }\end{array}$ & $\begin{array}{c}\text { ARTS } \\
\text { The International Journal of the Arts in Society. } \\
\text { Website: www.Arts-Journal.com }\end{array}$ \\
\hline $\begin{array}{c}\text { BOOK } \\
\text { The International Journal of the Book } \\
\text { Website: www.Book-Journal.com }\end{array}$ & $\begin{array}{c}\text { CLIMATE CHANGE } \\
\text { The International Journal of Climate Change: } \\
\text { Impacts and Responses } \\
\text { Website: www.Climate-Journal.com }\end{array}$ \\
\hline $\begin{array}{c}\text { CONSTRUCTED ENVIRONMENT } \\
\text { The International Journal of the } \\
\text { Constructed Environment } \\
\text { Website: www.ConstructedEnvironment.com/journal }\end{array}$ & $\begin{array}{c}\text { DESIGN } \\
\text { Design Principles and Practices: } \\
\text { An International Journal } \\
\text { Website: www.Design-Journal.com }\end{array}$ \\
\hline $\begin{array}{c}\text { DIVERSITY } \\
\text { The International Journal of Diversity in } \\
\text { Organizations, Communities and Nations } \\
\text { Website: www.Diversity-Journal.com }\end{array}$ & $\begin{array}{l}\text { FOOD } \\
\text { Food Studies: An Interdisciplinary Journal } \\
\text { Website: http://Food-Studies.com/journal/ }\end{array}$ \\
\hline $\begin{array}{c}\text { GLOBAL STUDIES } \\
\text { The Global Studies Journal } \\
\text { Website: www.GlobalStudiesJournal.com }\end{array}$ & $\begin{array}{c}\text { HEALTH } \\
\text { The International Journal of Health, } \\
\text { Wellness and Society } \\
\text { Website: www.HealthandSociety.com/journal }\end{array}$ \\
\hline $\begin{array}{c}\text { HUMANITIES } \\
\text { The International Journal of the Humanities } \\
\text { Website: www. Humanities-Journal.com }\end{array}$ & $\begin{array}{c}\text { IMAGE } \\
\text { The International Journal of the Image } \\
\text { Website: www.Onthelmage.com/journal }\end{array}$ \\
\hline $\begin{array}{l}\text { LEARNING } \\
\text { The International Journal of Learning. } \\
\text { Website: www.Learning-Journal.com }\end{array}$ & $\begin{array}{c}\text { MANAGEMENT } \\
\text { The International Journal of Knowledge, } \\
\text { Culture and Change Management. } \\
\text { Website: www.Management-Journal.com }\end{array}$ \\
\hline $\begin{array}{c}\text { MUSEUM } \\
\text { The International Journal of the Inclusive Museum } \\
\text { Website: www.Museum-Journal.com }\end{array}$ & $\begin{array}{c}\text { RELIGION AND SPIRITUALITY } \\
\text { The International Journal of Religion and } \\
\text { Spirituality in Society } \\
\text { Website: www.Religion-Journal.com }\end{array}$ \\
\hline $\begin{array}{c}\text { SCIENCE IN SOCIETY } \\
\text { The International Journal of Science in Society } \\
\text { Website: www.ScienceinSocietyJournal.com }\end{array}$ & $\begin{array}{c}\text { SOCIAL SCIENCES } \\
\text { The International Journal of Interdisciplinary } \\
\text { Social Sciences } \\
\text { Website: www.SocialSciences-Journal.com }\end{array}$ \\
\hline $\begin{array}{c}\text { SPACES AND FLOWS } \\
\text { Spaces and Flows: An International Journal of } \\
\text { Urban and ExtraUrban Studies } \\
\text { Website: www.SpacesJournal.com }\end{array}$ & $\begin{array}{c}\text { SPORT AND SOCIETY } \\
\text { The International Journal of Sport and Society } \\
\text { Website: www.sportandsociety.com/journal }\end{array}$ \\
\hline $\begin{array}{c}\text { SUSTAINABILITY } \\
\text { The International Journal of Environmental, Cultural, } \\
\text { Economic and Social Sustainability } \\
\text { Website: www.Sustainability-Journal.com }\end{array}$ & $\begin{array}{c}\text { TECHNOLOGY } \\
\text { The International Journal of Technology, } \\
\text { Knowledge and Society } \\
\text { Website: www.Technology-Journal.com }\end{array}$ \\
\hline $\begin{array}{c}\text { UBIQUITOUS LEARNING } \\
\text { Ubiquitous Learning: An International Journal } \\
\text { Website: www.ubi-learn.com/journal/ }\end{array}$ & $\begin{array}{l}\text { UNIVERSITIES } \\
\text { Journal of the World Universities Forum } \\
\text { Website: www.Universities-Journal.com }\end{array}$ \\
\hline
\end{tabular}

For subscription information please contact subscriptions@commongroundpublishing.com 